\title{
Radiological and Histological Assessment of Periapical Repair after Obturation of Infected Root Canals in Dogs
}

\author{
I. CAPÍK, Z. ŠEVČÍIOVÁ*, V. LEDECKÝ \\ Clinic of Surgery, Orthopaedics and Roentgenology, \\ *Department of Pathology, University of Veterinary Medicine, Košice, Slovak Republic
}

Received September 9, 2004

Accepted March 3, 2005

\begin{abstract}
Capík, I., Z. Ševčíková, V. Ledecký: Radiological and Histological Assessment of Periapical Repair after Obturation of Infected Root Canals in Dogs. Acta Vet. Brno 2005, 74: 237-242.

The study was conducted to compare efficiency of $1 \%$ chlorhexidine and calcium hydroxide as root canal disinfectants in dogs. Dogs treated at the clinic were randomly divided as follows: Group 1, onestep $(\mathrm{n}=12)$ - roots irrigated with $10 \mathrm{ml}$ of saline, obturated with gutta-percha and sealed with a composite; Group 2, $\mathrm{Ca}(\mathrm{OH})_{2}(\mathrm{n}=24)$ - after saline irrigation, a $\mathrm{Ca}(\mathrm{OH})_{2}$ dressing was applied to the canals using a lentulo spiral and teeth were temporized with zinc-phosphate cementum containing argentum (Argil, Dental Praha) for 2 weeks (after 2 weeks, the teeth were obturated as in Group 1); Group 3, $1 \%$ chlorhexidine $(\mathrm{n}=26)-1 \%$ chlorhexidine was applied into the root canals for two weeks and afterwards obturated as in Group 1).

Standardized radiographs taken six months later were used to assess the differences in the extent of periapical inflammatory reactions in the initial stage (part one of this study). At the same time sixteen teeth were surgically extracted for histological examination. Chlorhexidin and calcium hydroxide have shown similar endodontic therapeutic effect $(73.1 \%$ and $75.3 \%$ successfully treated teeth, respectively). However, in teeth treated with $1 \%$ chlorhexidine better periapical healing was achieved as shown by radiological signs.
\end{abstract}

Dog, root canal, periapical region, disinfectant, chlorhexidine, calcium hydroxide

Apical periodontitis is a common consequence of bacterial root canal contamination (Bergenholtz 1974; Fabricius et al. 1982; Fichtel 2000). When bacterial counts are decreased to the level undetectable by bacteriological methods, an extremely high success rate in the resolution of apical periodontitis can be expected (Sjogren et al. 1997). Complete débridement and irrigation of the root canal during the first appointment followed by application of calcium hydroxide dressing for one week or more is a scientifically documented procedure with the best results in canal disinfection of teeth with apical periodontitis (Sjorgen et al. 1991). Mechanical instrumentation alone causes a hundred 100 to 1000 -fold reduction in the number of bacteria, but complete elimination occurs in only 20 to $43 \%$ of cases (Bystrom and Sundquist 1981). Additional antibacterial irrigation with $0.5 \%$ sodium hypochlorite solution is used to disinfect from 40 to $60 \%$ of the treated cases (Bystrom and Sundquist 1996). A subsequent application of a $\mathrm{Ca}(\mathrm{OH})_{2}$ dressing may increase the percentage of bacteria-negative teeth to 90 to $100 \%$ (Bystrom et al. 1985). This treatment regimen thus represents a current standard for root canal disinfection.

One issue frequently debated in recent years is whether conscientious cleaning by instrumentation and irrigation does reduce the number of bacteria to a point where the obturation can be successful with this technique based on patient acceptance, lack of significant flare-ups, and practical management considerations. Because the current research indicates that one-step treatment of teeth with apical periodontitis is obturation of an infected canal in a relatively high percentage of patients, proponents of this technique rely on the lack of nutrition and space for 
bacterial multiplication to overcome the bacterial infection (Oliet 1983). Matsumiya and Kita mura (1960) suggested that entombment of bacteria will result in their death, even though in their study the canals were obturated with $\mathrm{Ca}(\mathrm{OH})_{2}$, an effective antibacterial agent, and it was not clear if the bacteria were viable or not. The purpose of the present study was to determine roentgenologically and histologically periapical healing of teeth with infected canals obturated with or without $\mathrm{Ca}(\mathrm{OH})_{2}$ or disinfected with $1 \%$ chlorhexidine.

\section{Materials and Methods}

This study was approved by the Ethical Committee of the University of Veterinary Medicine in Košice. Sixtytwo non-vital roots of fractured premolars, incisors an canines were used in dogs with a history of previous oral trauma or problematic food intake. Radiographs of all these dogs, treated at the Clinic of Surgery, Orthopaedics and Radiology, revealed the presence of periapical inflammation. All dogs treated in this study were used with owner agreement and all procedures were free of charge. The dogs were anaesthetized during all therapeutic and diagnostic procedures. The induction was achieved by intravenous administration of $0.5 \mathrm{mg} \cdot \mathrm{kg}^{-1}$ body mass of diazepam, and immediately after that with $4 \mathrm{mg} \cdot \mathrm{kg}^{-1}$ body mass of ketamine, followed by 1 to $2 \%$ isoflurane for the maintenance of anesthesia. All procedures were performed under strict aseptic conditions.

After the root canal exposure, all roots were instrumented to the size while clean dentinal shavings were obtained. The teeth were then randomly assigned to three groups as follows:Group 1, one-step $(\mathrm{n}=12)$ - each root was irrigated with $10 \mathrm{ml}$ of saline solution, obturated with gutta-percha using lateral condensation technique, and sealed with a composite (this group included dogs whose owners refused endodontic treatment but agreed that the dogs be included in the study and all dogs were treated with NSAD's - carprofenum $2 \mathrm{mg} \cdot \mathrm{kg}^{-1}$ daily throughout the study).

Group 2, $\mathrm{Ca}(\mathrm{OH})_{2}(\mathrm{n}=24)$ - the teeth were treated as in Group one, except that after saline irrigation, a $\mathrm{Ca}(\mathrm{OH})_{2}$ dressing was applied to the canals using a lentulo spiral and teeth were temporized with zinc-phosphate cementum containing silver (Argil, Dental Praha) for 2 weeks (after 2 weeks, the teeth were obturated as in Group 1).

Group 3, $1 \%$ chlorhexidine $(\mathrm{n}=26)$ - the teeth were treated as in group two but instead of a $\mathrm{Ca}(\mathrm{OH})_{2}$ dressing, $1 \%$ chlorhexidine was applied into the root canals for two weeks.

Standardized radiographs taken six months later were used to assess the differences in the extent of periapical inflammatory reactions in the initial stage (part one of this study).

At the same time sixteen teeth were surgically extracted. The roots of surgically extracted teeth contained two to three millimeters of periapical alveolar bone (part two of this study). The extracted teeth regularly presented the following radiological categories of increased or decreased periapical inflammatory reactions:

1. undetectable periapical inflammation

2. periapical inflammation increased (decreased) $1-25 \%$

3. periapical inflammation increased (decreased) $26-50 \%$

4. periapical inflammation increased (decreased) $51-99 \%$

The extracted teeth were fixed in a formaldehyde solution and decalcified with $5 \%$ formic acid. Individual blocks, containing the experimental roots and surrounding apical tissues, were cut and paraffin-embedded. Approximately 30 serial longitudinal sections 5 to $7 \mu \mathrm{m}$ thick were cut in a mesio-distal orientation. Every other section was subsequently stained with hematoxylin and eosin using standard procedures. An outside examiner selected three sections per root to be examined by two independent evaluators. The selected sections showed periapical tissues at least $1 \mathrm{~mm}$ from the end of the root. These sections were evaluated under a light microscope at $\times 10$ (20) magnification. The evaluators, one endodontist and one oral pathologist, were blinded to the treatment groups and evaluated the histological sections according to the following predetermined scale:

- $1=$ no inflammation (Plate XI, Fig. 1)

- 2 = mild inflammation and widened PDL space (Plate XI, Fig. 2)

- 3 = moderate inflammation and detectable loss of apical bone (Plate XII, Fig. 3)

- 4 = severe inflammation and severe destruction of apical and cortical bone (Plate XII, Fig. 4)

Statistical analysis

The difference between the means was tested using analysis of variance. ANOVA assumptions were tested using Levene's test (homogeneity of variances) and Shapiro-Wilk's test of normality. After significant ANOVA, we applied Bonferoni multiple comparison test to assess the significance of means.

\section{Results}

Radiographs were taken at the beginning of the study and six months later and differences in the extent of inflammatory reactions on radiographs were measured. Figures 5 and 6 show an increase and decrease in radiological periapical inflammatory extent.

Summary statistics of percent change of radiological periapical inflammatory extent for 
the three treatment groups are shown in Table 1. One-way analysis of variance was used to test for significance of the differences between the means of percent changes of radiological periapical inflammatory extent. Since F(2.59) $=6.99$ P-value $=0.002$, the difference between means of percent change of radiological periapical inflammatory extent was statistically significant at 1\% level (alpha) (Table 1, Fig. 7). Both ANOVA assumptions were met (homogeneity of variances tested using Levene's test and normality using Shapiro-Wilk's test). Coefficient $\eta 2$ (Eta squared) $=0.19$ which means that $19 \%$ of the total variability in "Change" is attributable to group affiliation.

Table 1. Descriptive statistics for percentage change

\begin{tabular}{|l|c|c|c|c|}
\hline & Calxyd & Chlorhexidin & Control & Total \\
\hline Count & 24 & 26 & 12 & 62 \\
\hline Mean & -23.29 & -36.46 & 29.83 & -18.53 \\
\hline Median & -25 & -40 & 37 & -21 \\
\hline $\begin{array}{l}\text { Standard } \\
\text { deviation }\end{array}$ & 57.69 & 52.16 & 32.19 & 56.24 \\
\hline Minimum & -100 & -100 & -53 & -100 \\
\hline Maximum & 80 & 100 & 75 & 100 \\
\hline
\end{tabular}

In order to assess which groups means differ, 95\% Bonferroni multiple range tests were applied (Table 2). The results show that the control group differed significantly from both chlorhexidin and calxyd groups, whereas the clorhexidin and calxyd groups do not differ among themselves.

Table 2. Bonferroni multiple comparison tests

\begin{tabular}{|l|c|c|c|}
\hline Group Is & Count & Mean & Treatment Groups \\
\hline chlorhexidin & 26 & -36.46 & control \\
\hline calxyd & 24 & -23.29 & control \\
\hline control & 12 & 29.83 & chlorhexidin, calxyd \\
\hline
\end{tabular}

Fig. 8 illustrates the distribution of all three groups within the inflammation score categories: $91.7 \%$ of the roots in group 1 were given a score of 4 (severe inflammation), compared with $16.7 \%$ for group 2 and $3.8 \%$ for group 3 . In group $2,20.8 \%$ of roots showed a score of $1,54.2 \%$ a score of 2 and $8.3 \%$ a score of 3 . In group $3,23.1 \%$ of roots received a score of $1.50 \%$ a score of 2 and $23.1 \%$ a score of 3 .

The score of 1 in histological sections was related to undetectable radiological periapical inflammation. Improvement of periapical inflammation from 1 to $86 \%$ corresponded to the score of 2 . The score of 3 was related to an increase in inflammatory reaction ranging between $1-25 \%$, and a higher degree of deterioration related to a score of 4 .

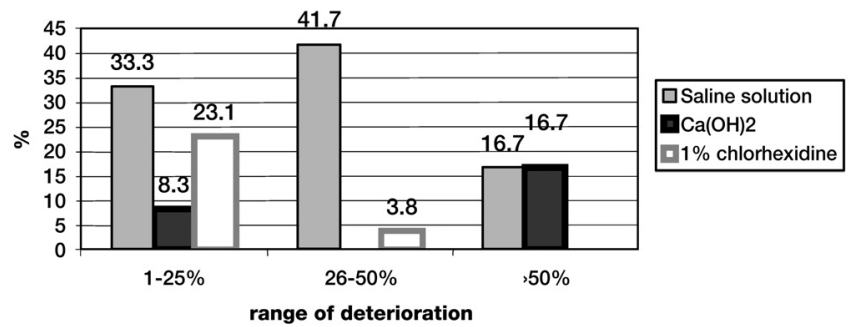

Fig. 5. Radiological periapical inflammatory extension 


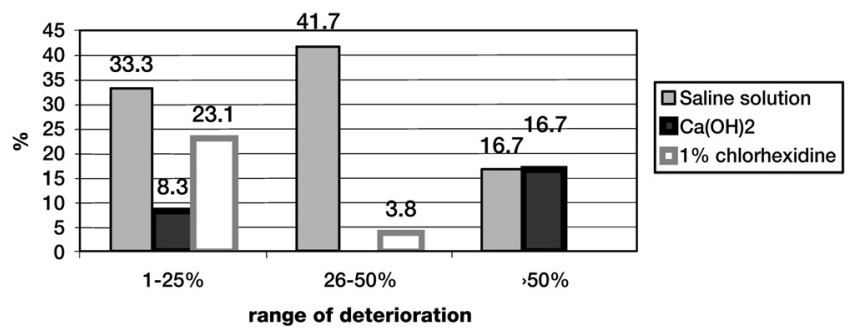

Fig.6. Radiological periapical inflammatory reduction

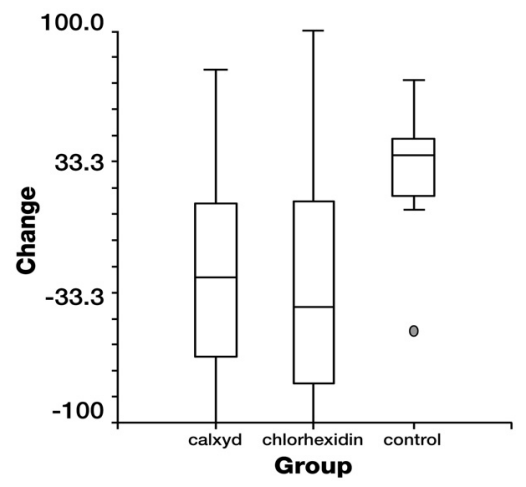

Fig. 7. Percentage change

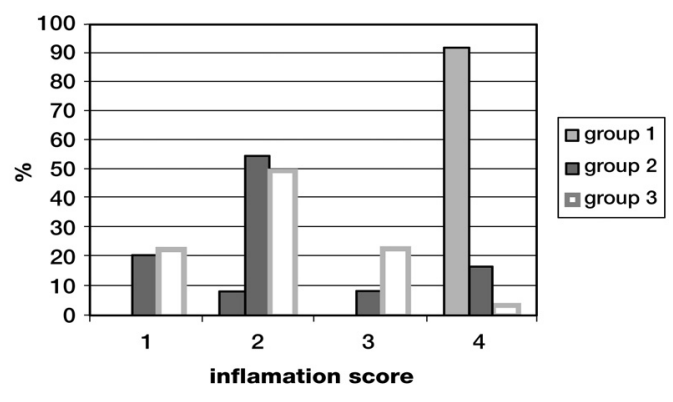

Fig. 8. Histological periapical repair

\section{Discussion}

Various traumatic injuries in the face region result in tooth fractures followed by periapical pathology (Fichtel et al. 2004). Bite wounds in the face region may also result in various dental traumas since $27.8 \%$ of all bite wounds are localised in face region in dogs (Baranyiová et al. 2003).

After endodontic therapy, root canal failure from persistent infection is a possibility. Continued infection of endodontically treated teeth may occur from bacteria residing within dentinal tubules. Obturation alone is also claimed to by significantly effective in reduction of periapical inflammation compared with an empty canal (Katebzadeh et al 1999). Increased success in reducing the risk of failure from infection has been noted for chemical disinfection of the root canal.

In this study we compared the effects of two root canal disinfectants, calcium hydroxide $\left(\mathrm{Ca}(\mathrm{OH})_{2}\right)$ and $1 \%$ chlorhexidine, acting for two weeks before permanent obturation. Our results did not confirm unambiguously the influence of obturation alone towards reducing periapical inflammation. Only in one case out of twelve the roots showed radiological signs of decreased periapical inflammation seen as periapical inflammatory reduction on the radiograph. The low rate of success achieved with obturation alone after biomechanical instrumentation seems to be associated only with the cases in which the root canals have been deprived of intracanal contamination following mechanical instrumentation.

Unfortunately, mechanical instrumentation alone is not very efficient in complete elimination of intracanal contamination. This is the main problem with long-lasting tooth fractures which are encountered commonly in veterinary dentistry (Pavlica 1998). 
The increased success achieved by the use of calcium hydroxide disinfection has been confirmed in recent studies (Sjogren et al 1997). A prospective radiographic study on humans showed superior clinical results for calcium hydroxide disinfection compared with one-step treatment of teeth with apical periodontitis.

Our study showed a similar effect of calcium hydroxide and $1 \%$ chlorhexidine. Both these disinfectants produced significant improvement in radiological inflammatory reactions. On the other hand, the extension of periapical inflammatory reaction was more pronounced in Group $2\left(\mathrm{Ca}(\mathrm{OH})_{2}\right), 16.7 \%$ of cases compared with Group 3 (1\% chlorhexidine) $3.8 \%$ of cases.

Whereas $16.7 \%$ of roots treated with $\mathrm{Ca}(\mathrm{OH})_{2}$ showed more than $50 \%$ of increase in periapical radiolucency in chlorhexidine group only $3.8 \%$ periapical radiolucencies increased in the range $26-50 \%$ in comparison with initial radiological findings. These results confirm, though not significantly, a better therapeutic effect of chlorhexidine to periapical repair of fractured non-vital teeth in dogs.

In conclusion, obturation alone of naturally fractured teeth and contaminated root canals did not reduce inflammation. $\mathrm{Ca}(\mathrm{OH})_{2}$, and $1 \%$ chlorhexidine as a root canal disinfectant had a remarkable influence on periapical inflammation but their efficacy did not differ significantly.

\section{Röntgenolgické a histologické posúdenie periapikálneho hojenia infikovaných koreňových kanálov psov}

Práca porovnáva terapeutický účinok $1 \%$ chlorhexidinu a hydroxidu vápenatého na elimináciu periapikálneho zápalového procesu u psov ošetrovaných v klinickej praxi. Na histologické vyšetrenie boli použité zuby psov, ktorých majitelia žiadali extrakciu zubov ako spôsob terapie zlomených zubov. Pred bezplatnou extrakciou súhlasili s použitím psov v práci. Ošetrované zuby boli rozdelené do troch skupín: 1 . skupina $(n=12)-$ mechanicky opracované koreňové kanály s použitím $10 \mathrm{ml}$ fyziologického roztoku ako iriganta boli vysušené, obturované guttaperčou a prístupové otvory päčatené svetlom tuhnúcim kompozitom; 2. skupina $\mathrm{Ca}(\mathrm{OH})_{2} \quad(\mathrm{n}=24)$ - koreňové kanály boli opracované ako v prvej skupine a nanasledujúce 2 týždne bol aplikovaný $\mathrm{Ca}(\mathrm{OH})_{2}$ (následne boli postihnuté zuby permanentne obturované ako v prvej skupine); 3 . skupina, $1 \%$ chlorhexidin $(n=26)-$ po mechanickom opracovaní bol do koreňových kanálov aplikovaný na dva týždne $1 \%$ chlorhexidin.

V čase ošetrenia a s odstupom pol roka boli zhotovené štandardné radiogramy na posúdenie rozdielov v rozsahu periapikálneho zápalu. Šestnást̉ zubov bolo chirurgicky extrahovaných a použitých na histologické posúdenie periapikálnych tkanív. Zápalové zmeny prestupujúce na periapikálny cement a dentin boli diagnostikované pri zväčšovaní rozsahu zápalu do $25 \%$ oproti počiatočnému stavu. Zväčšenie zápalu nad $25 \%$ bolo sprevádzané aj deštukciou alveolárnej kosti. Dezinfekčný účinok $1 \%$ chlorhexidinu podla dosiahnutých výsledkov je analogický dezinfekčnému účinku hydroxidu vápenatého.

\section{Acknowledgement}

This study was supported by Scientific Grant Agency of Ministry of Education of the Slovak Republic and Slovak Academy of Sciences No. 1/0566/03.

\section{References}

BARANYIOVÁ E, HOLUB A, MARTINÍKOVÁ M, NEČAS A, ZATLOUKAL J 2003: Epidemiology of intraspecies bite wounds in dogs in the Czech Republic. Acta Vet Brno 72: 55-62

BERGENHOTZ G 1974: Micro-organisms from necrotic pulps of traumatised teeth. Odontol Rev 25: $347-351$

BYSTROM A, SUNDQUIST G 1981: Bacteriological evaluation of the efficacy of mechanical root canal instrumentation in endodontic therapy. Scan J Dent Res 89: 321-328 
BYSTROM A, SUNDQUIST G 1983: Bacteriological evaluation of the effect of $0.5 \%$ sodium hypochlorite in endodontic therapy. Scan J Dent Res 55: 307-312

BYSTROM A, CLEASSON R, SUNDQUIST G 1985: The antibacterial effect of camphorated paramonochlorophenol, camphorated phenol, and calcium hydroxide in the treatment of infected rot canals. Endod Dent Traumatol 1: 170-1755

FABRICIUS L, DAHLEN G, OHMAN AE, MOLLER AJR 1982: Predominant indigenous oral bacteria isolated from infected root canals after varied times of closure. Scand J Dent Traumatol 90: 133-144

FICHTEL T 2000: Periapical granuloma of upper canine. Veterináfiství 6: 228-229

FICHTEL T, CRHA M, VLAŠIN M, RAUŠER P, PRANTL H, PAVLICA Z 2004: Aetiology of apical parodontitis in the fourth maxilar premolar in dogs. Kleintierpraxis 49: 261-328

KATEBZADEH N, HUPP J, TROPE M 1999: Histological periapical repair after obturation of infected root canals in dogs. J Endodon 25: 364-368

MATSUMIYA S, KITAMURA M 1960: Histopathological and histobacteriological studies of the relation between the condition of sterilisation of the interior of the root canal an the healing process of periapical tissues in experimentally infected root canals. Bull Tokyo Dental Coll 1: 1-19

OLIET S 1983: Single-visit endodontics: a clinical study J Endodon 9: 4-7

PAVLICA Z 1998: Endodontija mleãnyh in nedoraslih stalnih zob.Vet Nov 24: 299-304

SJOGREN U, FIGDOR D, PERSSON S, SUNDQUIST G 1997: Influence of infection at the time of root filling on the outcome of endodontic treatment of teeth with apical periodontitis. Int Endod J 30: 397-406

SJOGREN U, FIGDOR D, SPANDBERG L, SUNDQUIST G 1991: The antimicrobial effect of calcium hydroxide as a short-term intracanal dressing. Int Endod J 24: 119-125 
Plate XI

Capík I. et al.: Radiological and Histological ... pp. 237-242

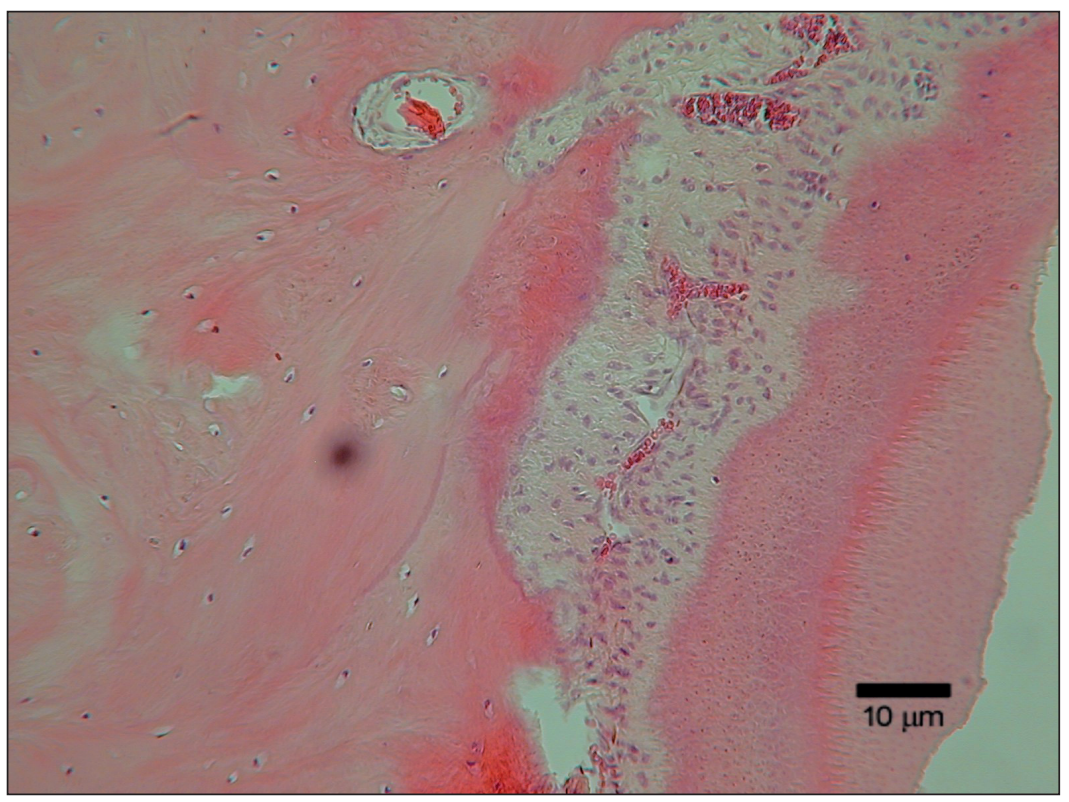

Fig. 1. No inflammation of periodontal space, $\mathrm{HE}, \times 20$, bar $10 \mu \mathrm{m}$

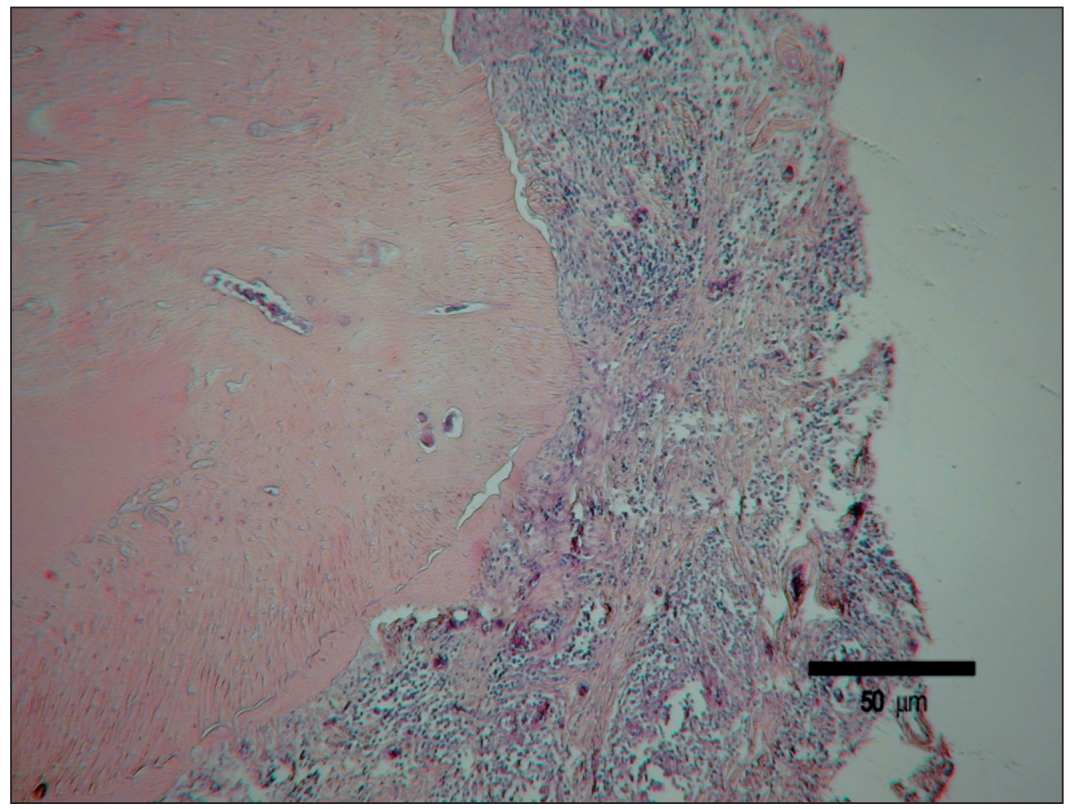

Fig. 2. Widened periodontal space with fibrosis of periodontal ligament, HE, $\times 10$, bar $50 \mu \mathrm{m}$ 


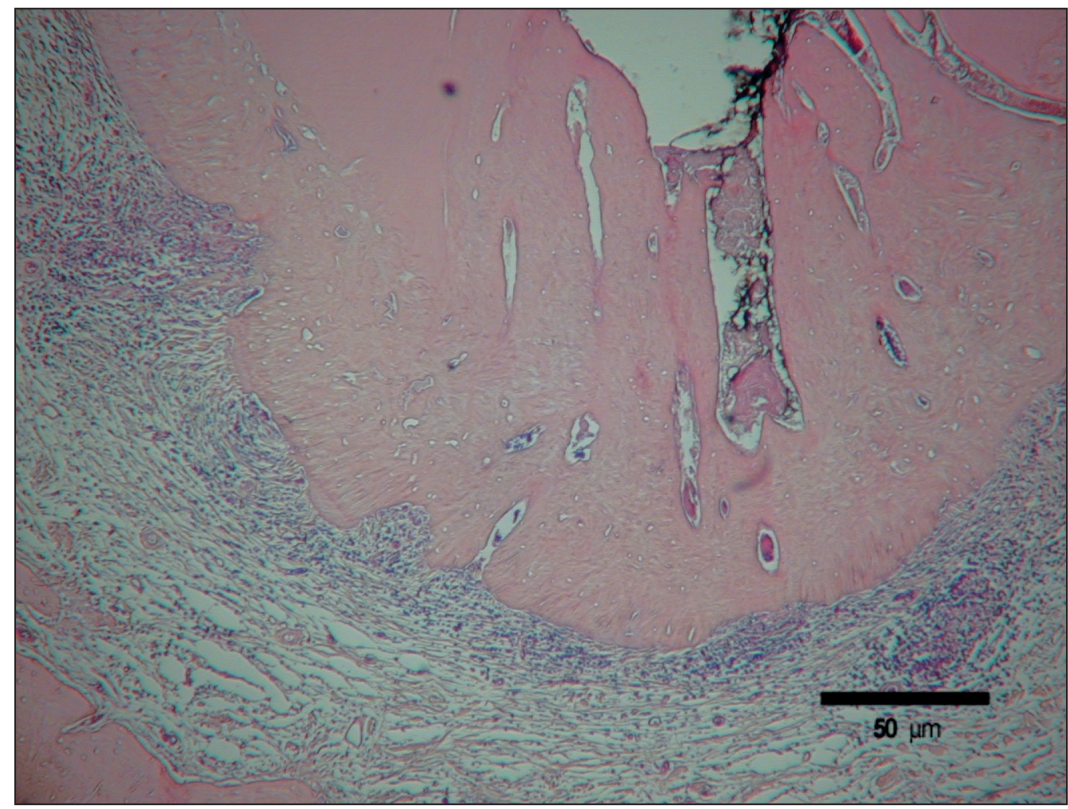

Fig. 3. Inflammation with detectable loss of apical bone, HE, $\times 10$, bar $50 \mu \mathrm{m}$

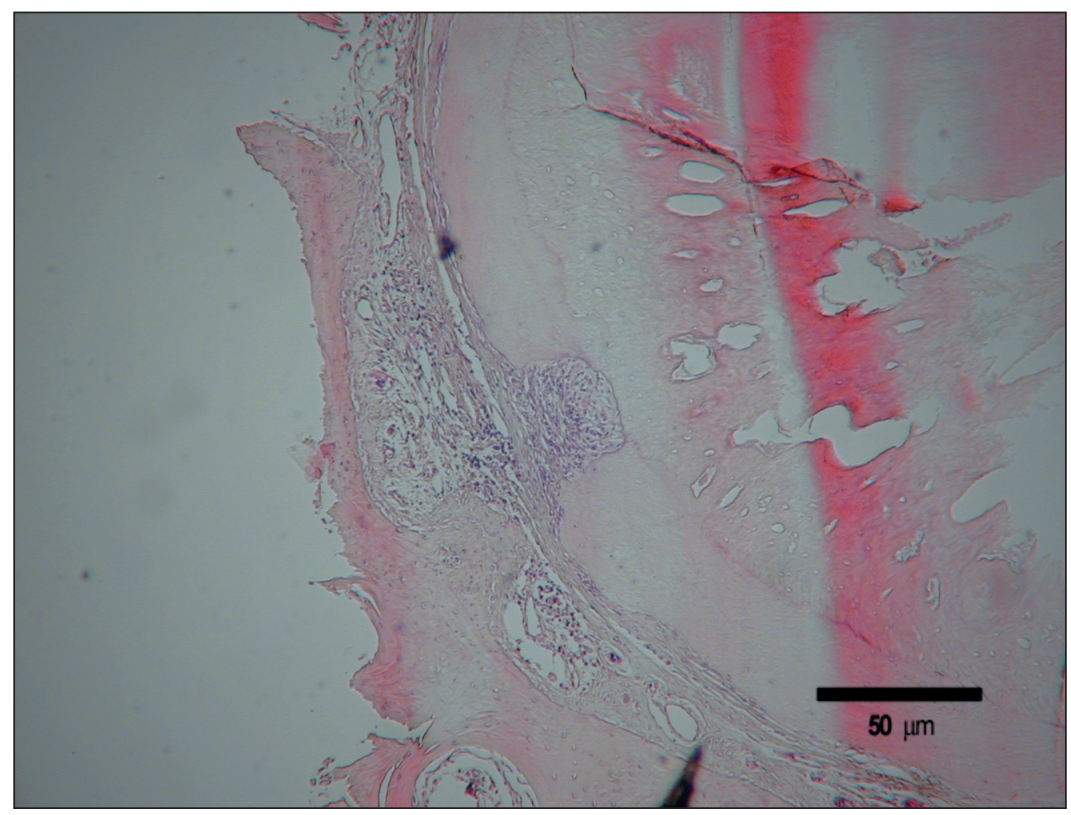

Fig. 4. Inflammation and destruction of apical and cortical bone, HE, $\times 10$, bar $50 \mu \mathrm{m}$ 